\title{
Ultrastructure and biochemical traits of bread and durum wheat grains under heat stress
}

\author{
Ana S. Dias ${ }^{1 *}$, Ana S. Bagulho ${ }^{2}$ and Fernando C. Lidon ${ }^{1}$ \\ ${ }^{1}$ Grupo de Disciplinas de Ecologia da Hidrosfera, Faculdade de Ciências e Tecnologia, Universidade Nova de \\ Lisboa, Quinta da Torre, 2829-516 Caparica, Portugal. \\ 2 Estação Nacional de Melhoramento de Plantas, Instituto Nacional dos Recursos Biológicos, Elvas, Portugal.
}

*Corresponding author: anasofia.almeida@gmail.com.

Received: 25 June 2008; Returned for revision: 06 August 2008; Accepted: 19 August 2008

\begin{abstract}
ULTRASTRUCTURE AND BIOCHEMICAL TRAITS OF WHEAT GRAINS UNDER HEAT STRESS: The yield and grain quality (as well as technological traits) of two heat-stressed genotypes of bread (Triticum aestivum L.) and durum wheat (Triticum turgidum subsp. durum) having different tolerance to high temperatures after anthesis were investigated. Heat stress, during grain filling, triggered grain shrinkage with a reduced weight and ultrastructural changes in the aleurone layer and in the endosperm cells. Heat stress also decreased the sedimentation index SDS, an effect associated with increased protein content in the grain but with decreased levels of essential amino acids. Although the responses to heat stress were similar among the Triticum genotypes, it is further suggested that during grain filling, high temperatures might affect gluten strength, hence diminishing the wheat flour quality.
\end{abstract}

Key Words: grain weight, grain quality, high temperature, Triticum aestivum, Triticum turgidum subsp. durum

Características bioquímicas e ultraestruturais de grãos de trigo mole e trigo rijo sob estresse térmico: A produção e a qualidade do grão (incluindo alguns aspectos da qualidade tecnológica) sob estresse térmico, durante o enchimento do grão, foram avaliadas em dois genótipos de trigo mole (Triticum aestivum L.) e trigo rijo (Triticum turgidum subsp. durum) com diferentes tolerâncias às temperaturas elevadas após a antese. 0 estresse térmico, após a antese, induziu 0 desenvolvimento de grãos enrugados e com peso reduzido. Observaram-se ainda modificações ultraestruturais em nível da camada de aleurona e nas células do endosperma. Os grãos submetidos a temperaturas mais elevadas mostraram índices de sedimentação SDS menores, tendo estado este efeito associado a um aumento nos teores em proteína do grão e ainda a um decréscimo nos níveis de aminoácidos essenciais. Apesar das respostas às temperaturas elevadas não terem sido diferenciadas entre os genótipos de trigo, os resultados sugerem que 0 estresse térmico, durante o período de enchimento do grão, pode afectar a força do gluten, diminuindo a qualidade da farinha de trigo.

Palavra-chaves: Triticum aestivum, Triticum turgidum subsp. Durum, grãos de trigo

\section{INTRODUCTION}

During the growth cycle of the wheat crops, the optimal mean temperature might vary between $15-18^{\circ} \mathrm{C}$ (Chowdhury and Wardlaw, 1978), with $20^{\circ} \mathrm{C}$ being the optimum value for grain filling (Dupont and Altenbash, 2003). Several studies conducted in Australia and USA (Wardlaw and Wrigley, 1994) further indicated that each year, crop production decreases about $10-15 \%$, mostly due to high temperatures during anthesis. It was also pointed out (Wardlaw et al., 1989) that a global reduction in crop production of about 3-4\% occurs when the mean temperature increases by $1^{\circ} \mathrm{C}$ above the optimum 
value. In this context, even water is not a limiting factor, Triticum productions with late sowing in Mediterranean environments (where high temperatures occur at the end of the cycle) have lowered yields, mostly as a result of heat stress during grain filling (McDonald et al., 1983; Maçãs et al., 1999, 2000). Following this pattern Sofield et al. (1977) showed that, after anthesis, high temperatures (between $15 / 10^{\circ} \mathrm{C}$ and $21 / 16^{\circ} \mathrm{C}$ ) counterbalance a diminished duration of growth, increasing the filling rate (although also triggering a small variation in grain weight). Yet, with higher temperatures, ranging between $21 / 16^{\circ} \mathrm{C}$ and $30 / 25^{\circ} \mathrm{C}$, those authors further pointed out that the grain filling rate did not display a compensatory increase when correlated with its duration period (thus, leading to a significant reduction of the grain weight at maturity).

It has long been known (Spiertz, 1974) that with high temperatures after anthesis, increasing leaf senescence is coupled to a significant increase in the respiration rates in the grain. Such a response, depending on its extent, might trigger decreased carbohydrate availability (Thornley, 1971), justifying the decline in grain weight. Jenner (1991), further supported by Nicolas et al. (1984) in their work on sucrose concentrations (in the grain and endosperm) made a similar proposal, concluding that after anthesis heat stress affects wheat grain quality through changes in protein composition. During grain filling, under heat stress, the decreased grain weight (and, therefore, the yield reduction) also diminishes wheat flour production (Guedira et al., 2002). Additionally, gluten strength and flour quality for breadmaking, although highly linked to the genotype (Branlard and Dardevet, 1985), are also affected by environmental conditions (Rharrabti et al., 2001). Environmental conditions affect the protein concentration, a parameter associated with the definition of Triticum grain quality, as well as gluten strength. In this context, breadmaking quality of bread wheat depends on the viscoelasticity properties of dough, which are affected by the composition and quantity of the gluten proteins in the endosperm (Wang et al., 2005). Accordingly, a high correlation has been found for protein content and texture and volume of the cooked bread (Pomeranz, 1988).

From previous studies on heat stress after anthesis, our research group found that Triticum aestivum L. genotype Sever is more tolerant than the Golia genotype (Maçãs et al., 1999) and that tolerance of Triticum turgidum subsp. durum genotype TE 9306 prevailed relative to the genotype
Acalou (Maçãs et al., 2000). In this study, these genotypes were submitted to heat stress during anthesis, in order to characterize the modifications related to grain quality.

\section{MATERIALS AND METHODS}

Genotypes and growth conditions: Bread wheat (Triticum aestivum L. genotypes Sever and Golia) and durum wheat (Triticum turgidum subsp. durum genotypes TE 9306 and Acalou) grains were washed in distilled water and sterilized by immersion in mercury dichloride solution (1:1000) for 2 min. Subsequently, the grains were washed five times in deionized water and placed in an oven at $28^{\circ} \mathrm{C}$ for $24 \mathrm{~h}$. Immediately thereafter the seeds were transferred to a greenhouse and grown in $25 \times 21 \mathrm{~cm}$ pots containing a 1:1 perlite and vermiculite mixture. The experiment was conducted using 136 pots. Half of these pots were placed under heat stress after anthesis. For each genotype 17 replicates were used (with and without heat stress). Ten seeds were grown per pot and two weeks later five plants were selected, and the others discarded. Accordingly, 680 plants were used. During all the experiment the position of the pots was changed weekly in order to minimize the effects due to irradiance variations. Plants were irrigated weekly, alternating distilled water and a standard nutrient solution (in $\mathrm{mL}$ per $100 \mathrm{~L}$, starter/pre-anthesis/post-anthesis, Ca $\left(\mathrm{NO}_{3}\right)_{2}$ 100/100/50; $\mathrm{KNO}_{3}$ 50/200/100; $\mathrm{KH}_{2} \mathrm{PO}_{4}$ 100/100/100; $\mathrm{MgSO}_{4}$ 200/200/100; $\mathrm{K}_{2} \mathrm{SiO}_{3}$ 100/100/0; $\mathrm{Fe}\left(\mathrm{NO}_{3}\right)_{3}$ 20/5/5; EDTA 25/5/5; $\mathrm{MnCl}_{2}$ 5/10/5; $\mathrm{ZnSO}_{4}$ 20/10/10; $\mathrm{H}_{3} \mathrm{BO}_{3}$ 10/5/2; $\mathrm{CuSO}_{4}$ 5/5/3; $\mathrm{Na}_{2} \mathrm{MoO}_{4}$ 15/5/5). During the vegetative and reproductive growth, plants were kept under natural light, between March and May in Lisbon, Portugal $\left(38^{\circ} 42^{\prime} \mathrm{N}\right.$; $9^{\circ} 05^{\prime} \mathrm{W}$ ) with a photoperiod varying between 12 and $14 \mathrm{~h}$ and a mean daily temperature of $19^{\circ} \mathrm{C}$. At anthesis, the plants were separated into two groups and each was submitted to a different temperature treatment (control and heat stress) in two different greenhouses.

Temperature treatments: Plants under the control treatment were grown with mean day/night temperatures of $25 / 14^{\circ} \mathrm{C}$ and plants submitted to heat stress with a mean regime of $31 / 20^{\circ} \mathrm{C}$ (Figure 1). The average day/night temperatures were calculated as the mean of readings taken every $2 \mathrm{~h}$, over each $24 \mathrm{~h}$ period. Additionally, they were also submitted to short periods with mean daily temperatures above $32^{\circ} \mathrm{C}$ (21-24 April and 19 May 2002). 


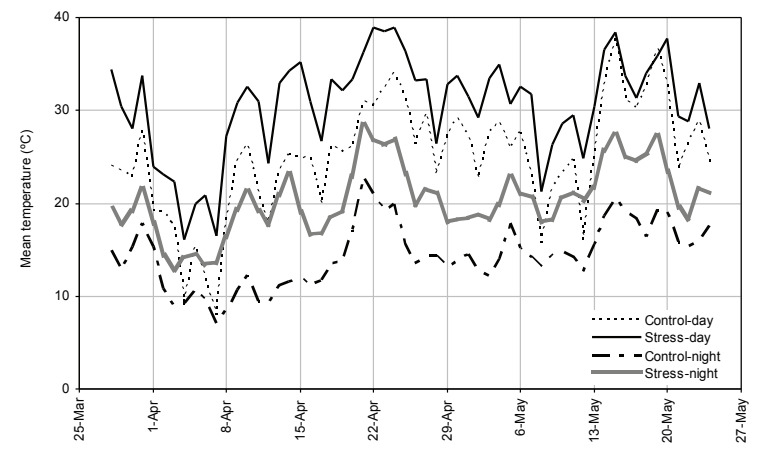

Figure 1. Daily mean temperature of day and night periods, during the grain filling period, for control and heat stress treatments.

Yield components: Tillers were removed periodically from each plant, leaving just the main stem. At physiological maturity (that is, when the maximum grain weight was reached), the selected plants were harvested and dried at $80^{\circ} \mathrm{C}$, for $48 \mathrm{~h}$. The numbers of spikelets and grains in each spike were recorded, as well as the grain weight. The individual grain weight was calculated dividing the yield per spike by the number of grains per spike.

Grain ultrastruture: Grains were used for observations with a scanning electron microscopy according to Hall and Hawes (1991). Samples were dried with $\mathrm{CO}_{2}$ using a Balzers union CPD 020 (England), and then metallized with an EM Scope for the gold-paladium metalization. A scanning IST-DS130 microscope (Akashi Beam Technology, Tokyo, Japan) was used.

Total and reducing sugars: Grain in powder form (100 $\mathrm{mg}$ ) was mixed with $10 \mathrm{~mL}$ deionized water and boiled in a water bath during $5 \mathrm{~min}$. After cooling, the extract was diluted with deionized water and Sumner reagent (Sumner, 1925) was added (1:20:1 v/v/v). Twenty five milliliters of this mixture was boiled for $5 \mathrm{~min}$ and, after cooling, the initial volume was restored with deionized water. For the determination of reducing sugars, the absorbance of this mixture was read at $540 \mathrm{~nm}$ (Lindsay 1973). For total sugar analysis, $5 \mathrm{~mL}$ of the extract were incubated with $12.5 \mu \mathrm{L}$ of invertase (commercial grade -Sigma l-9253), at $30^{\circ} \mathrm{C}$ during $2 \mathrm{~h}$. Thereafter, $2 \mathrm{~mL}$ of this extract were mixed with $2 \mathrm{~mL}$ of Sumner reagent (Sumner 1925) and boiled for $5 \mathrm{~min}$. After cooling, the volume was brought to $25 \mathrm{~mL}$ with deionized water and the absorbance measured at $540 \mathrm{~nm}$ (Lindsay 1973).

Grain amino acids: Amino acids were extracted from the grains (ca. $2 \mathrm{~g}$ ), using $2 \mathrm{~mL}$ of a solution containing methanol, chloroform and water $(12: 5: 3 \mathrm{v} / \mathrm{v} / \mathrm{v})$. After centrifugation, $0.8 \mathrm{~mL}$ of water and $0.53 \mathrm{~mL}$ of chloroform were added to the supernatant. Five minutes later, the aqueous phase was removed and transferred to an eppendorf tube and the organic phase was further extracted with $1 \mathrm{~mL}$ of water. This second aqueous phase was removed and mixed with the first one. After adding trifluoroacetic acid (TFA) to the aqueous phase $(1: 2 \mathrm{v} / \mathrm{v})$ and centrifuging for $15 \mathrm{~min}$, the supernatant was removed and frozen at $-80^{\circ} \mathrm{C}$, during $5 \mathrm{~min}$, and taken to dryness in a Speed-Vac. For sample hydrolysis, $1 \mathrm{~mL}$ of the aqueous phase was mixed with $\mathrm{HCl} 6 \mathrm{M}$ containing phenol (1 $\mathrm{mg} \mathrm{mL}^{-1}$ ) and the sample was kept at $110^{\circ} \mathrm{C}$ for $24 \mathrm{~h}$. Thereafter, the sample was dried. Amino acids were quantified according to Hayakawa and Oizumi (1989) after isocratic separation by reverse phase HPLC (Shimadzu, Japan). A NUCLEOSIL $5 C_{18}$ $250 \times 4.6 \mathrm{~mm}$ column and an eluente mixture containing acetonitrile: water (40:60 v/v) with $0.1 \%$ TFA (at a flow rate of $1.0 \mathrm{~mL} \mathrm{~min}^{-1}$ ) were used. The effluent was monitored at 269 $\mathrm{nm}$. The amino acids were identified in the chromatogram by comparison with an amino acid standard mixture (Sigma).

Mineral analysis: For the determination of $\mathrm{Ca}, \mathrm{K}, \mathrm{Mg}$, $\mathrm{Na}, \mathrm{Cu}, \mathrm{Zn}, \mathrm{Fe}$ and $\mathrm{Mn}, 1.0 \mathrm{~g}$ of dry material, from each sample, was mineralized by incineration at $\sim 550^{\circ} \mathrm{C}$, followed by nitric acid digestion (Vandecasteele and Block, 1993). A Unicam model 939 atomic absorption unit (Cambridge, UK), equipped with a hollow cathode lamp was used for the metal determinations. For the measurement of $\mathrm{P}$ concentrations, hot digestion with $\mathrm{HNO}_{3}$ and $\mathrm{H}_{2} \mathrm{SO}_{4}$ (Watts and Halliwell, 1996) was carried out. Phosphates were determined by a molecular absorption Unit (Cecil 9000 series, Cambridge, UK), following the formation of a chromophore with ammonium molybdate, in the presence of ascorbic acid and potassium antimonyl tartrate trihydrate (Watanabe and Olsen, 1965).

Wheat technological quality: Protein content and hardness were evaluated by near-infrared reflectance spectroscopy using an Inframatic 8620 system (Perten, France), according to the AACC methods 39-25 and 39-70A, respectively. The sodium dodecyl sulfate (SDS) sedimentation test was performed on whole flour samples, as described by 
Dick and Quick (1983). All quality parameters were evaluated using three replications for each genotype/treatment.

Statistical analysis: Statistical analysis was performed with a two-way ANOVA ( $P \leq 0.05)$, using STATISTICA, version 6 (2001), by StatSoft, Inc (Tulsa, OK, USA). In figures, each value represents the mean $\pm S E$ of three replicates and different letters indicate significant difference between means.

\section{RESULTS AND DISCUSSION}

During grain growth, the high temperature treatment $\left(31 / 20^{\circ} \mathrm{C}\right.$, as opposed to $\left.25 / 14^{\circ} \mathrm{C}\right)$ promoted both, grain shrinkage (Figures 2 and 3 ) and a decrease in weight (Table 1). The individual grain weight was more affected by high temperatures in the durum wheat genotypes as compared to bread wheat (relative to the control, $17 \%$ and $14 \%$ reduction, respectively). In the heat-stressed Sever genotype, relative to Golia, grain weight was significantly higher due to a superior potential grain weight (Table 1). Under heat stress, TE 9306 showed a lower grain weight reduction compared to Acalou but, despite displaying a lower potential, it did have a higher final grain weight (Table 1). Accordingly, as previously reported (Sofield et al., 1977; Chowdhury and Wardlaw, 1978; Wardlaw et al., 1989), our data also indicate that grain weight is affected by high temperatures after anthesis, with the temperature $\mathrm{x}$ genotype interaction being highly significant (Table 1) suggesting the occurrence of genetic variability (Wardlaw et al., 1989).

In the absence of heat stress, the unique aleurone layer of the wheat kernel presented large cells (Figures 2 and 3), surrounding a starchy endosperm (Bradbury et al., 1956). During grain filling, the shrunken grains of Acalou and Sever showed an aleurone layer with disordered cells, but in Golia and in TE 9306 cell arrangement of this layer remained unchanged (Figures 2 and 3). Under heat stress, the endosperm of the kernels also seemed to be increasingly aggregated, with the starch granules, as previously observed by Pyler (1988), embedded in the protein matrix and a dense cellular structure (Figures 2 and 3). Several authors (Bechtel et al., 1986) showed that different types of starch granules can be found: A-type (lenticular shaped) starch granules, and B-type (spherical shaped). In Golia, the endosperm of the grains showed a higher cohesion compared to Sever (Figure 2). The grains developed under high temperatures also revealed deformed starch granules in the endosperm (Figures 2 and 3), as also found by Shi et al. (1994), with lower protein adherence.

Genetic tolerance to high temperature (associated with drought) in wheat is observed at later phases of plant development, i.e., shooting and heading (Wiśniewski and Zagdańska, 2001). It is well known that soluble sugars play a complex essential role in plant metabolism as products of hydrolytic processes, substrates in biosynthetic processes and energy production as well as in a sugar sensing and signaling systems. Recently, it has been claimed that sugar flux may be a signal for metabolic regulation (Gibson, 2005), with the mobilization of storage reserves in the endosperm of cereal seeds being tightly regulated and having a primary pivotal role in the response to high temperatures associated with drought (Finkelstein and Gibson, 2001). In our study, although the concentrations of total sugars in bread and durum wheat during grain filling were not significantly affected by high temperatures, the levels of reducing sugars increased in Golia, while no significant variation was found in Sever and a decrease was recorded for TE 9306 (Table 2). According to Leon and Sheen (2003), this pattern might be considered a tolerance signal, possibly developmentally regulated, modulated by the sugar pool and implying genetic variability in Triticum species.

Table 1. Effect of heat stress on grain weight of the bread and durum wheat genotypes. For each Triticum species, different letters in the same column refer to significant differences between genotypes. ${ }^{* *}=P<0.01$ and $* \star *$ $=P<0.001 ; \mathrm{G} \times \mathrm{E}=$ genotype $\mathrm{x}$ environment interaction .

\begin{tabular}{|c|c|c|c|}
\hline Genotype & Control & Heat stress & $G \times E$ \\
\hline \multicolumn{4}{|c|}{ Individual grain weight (mg) } \\
\hline Bread wheat mean & $56.54 \pm 1.08$ & $48.73 \pm 0.90 * * *$ & $* * *$ \\
\hline Golia & $47.11 \pm 0.84 a$ & $43.75 \pm 0.90 \mathrm{a} * *$ & \\
\hline Sever & $64.67 \pm 1.03 b$ & $\underset{\star \star \star \star}{53.53 \pm 1.23 b}$ & \\
\hline Durum wheat mean & $72.06 \pm 0.60$ & $59.97 \pm 0.61 * * *$ & $\star \star \star *$ \\
\hline Acalou & $72.42 \pm 0.70 \mathrm{a}$ & $\underset{* \star *}{57.69 \pm 0.86 a}$ & \\
\hline TE 9306 & $71.74 \pm 0.95 a$ & $\underset{* \star *}{62.55 \pm 0.70 \mathrm{~b}}$ & \\
\hline
\end{tabular}



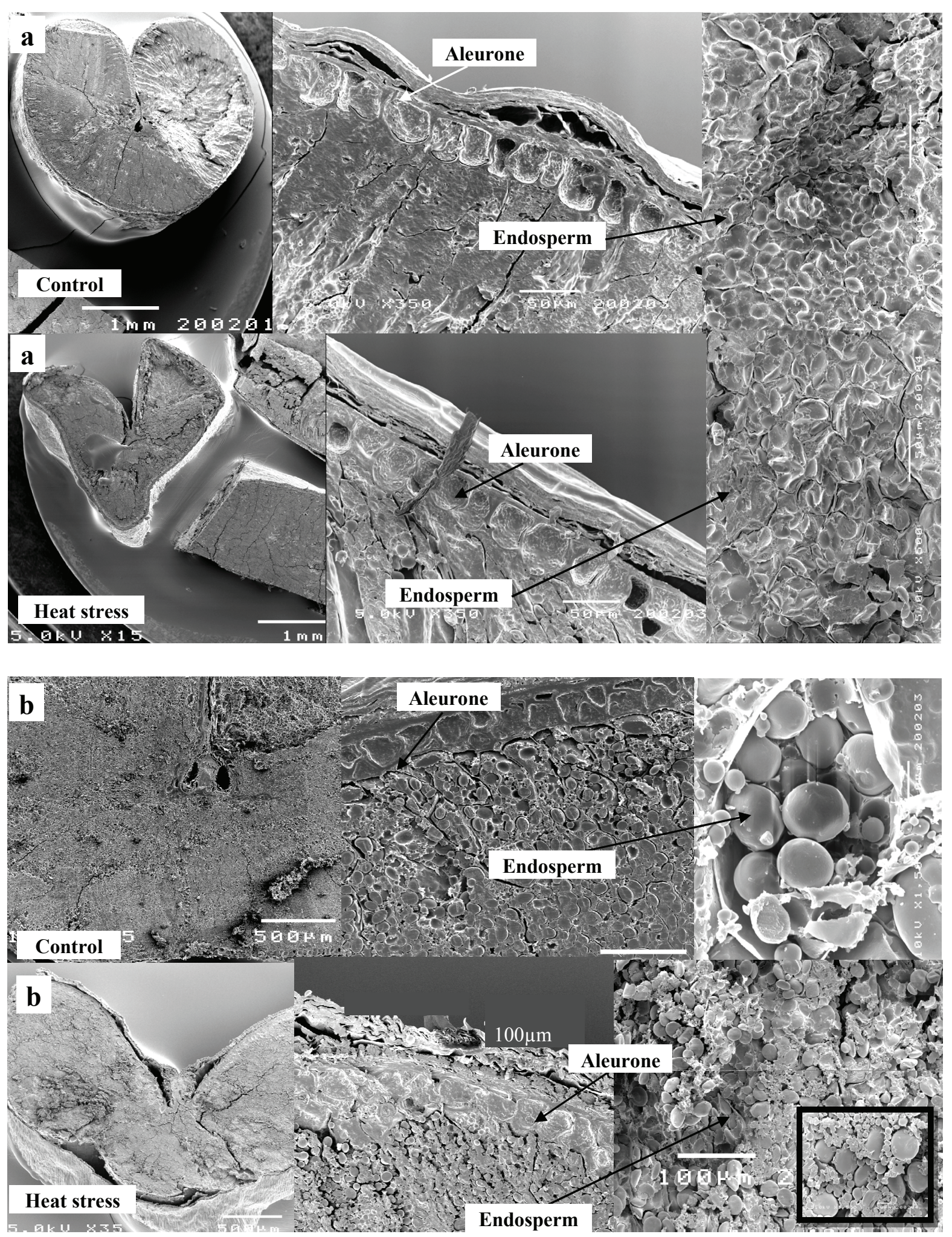

Figure 2. Scanning electron microscopy of kernels of control and heat stressed Triticum aestivum (A, Golia; B, Sever). Figures are representative of the three replicates per each genotype and treatment. 

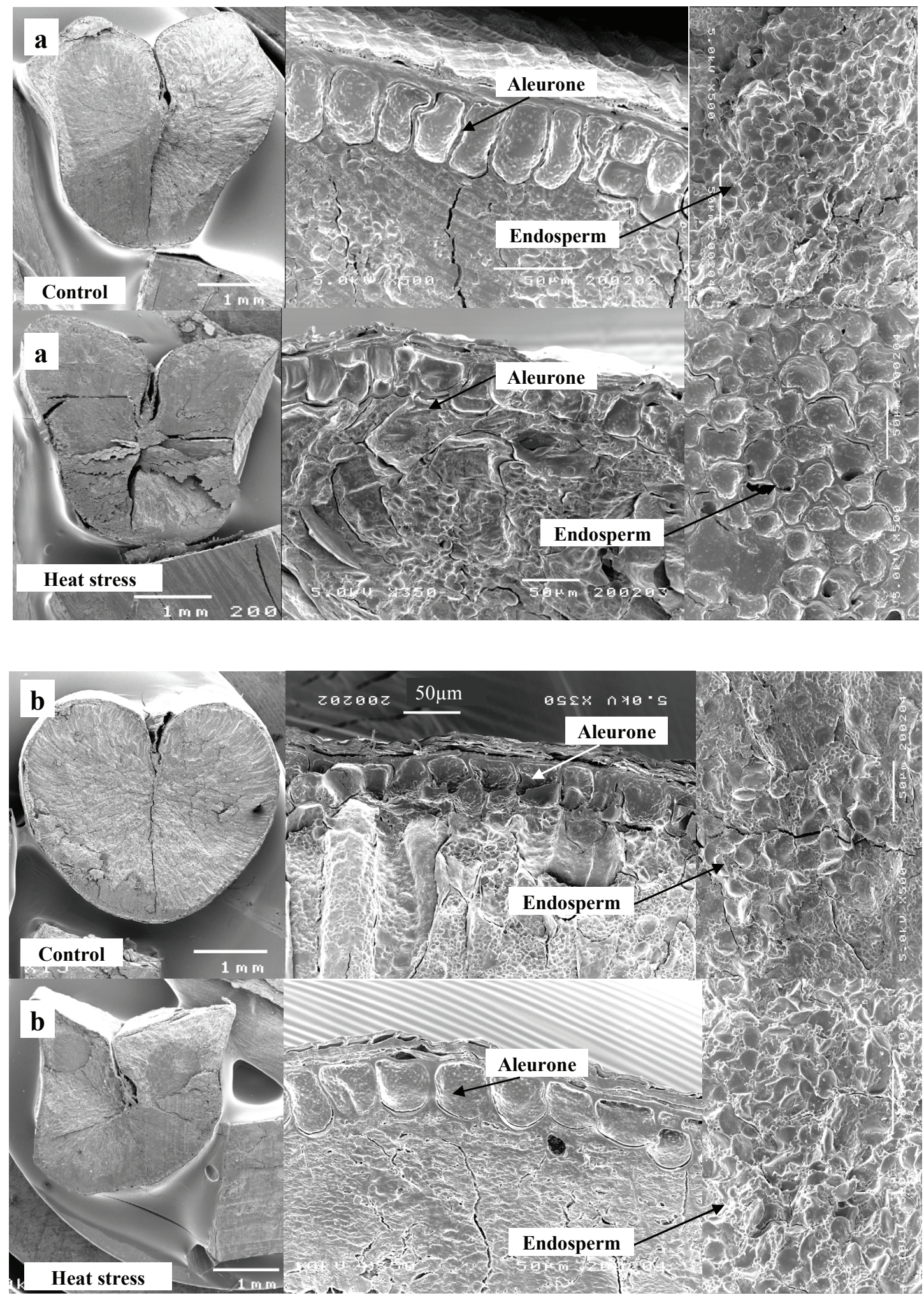

Figure 3. Scanning electron microscopy of kernels of control and heat stressed Triticum aestivum (A, Acalou; B, TE 9306). Figures are representative of the three replicates per each genotype and treatment. 
Table 2. Reducing and total sugars in mature kernel of bread and durum wheat genotypes. For each Triticum species, values are presented on a dry weight basis, where different letters in the same column refer to significant differences between genotypes. Data represents the mean of three replicates \pm SE; ns $=$ nonsignificant; ${ }^{*}=P<0.05 ;{ }^{* *}=P<0.01$.

\begin{tabular}{|c|c|c|c|c|}
\hline & \multirow{2}{*}{\multicolumn{2}{|c|}{ Reducing sugars (\%) }} & & \\
\hline & & & \multicolumn{2}{|c|}{ Total sugars (\%) } \\
\hline & Control & Heat stress & Control & Heat stress \\
\hline Golia & $1.15 \pm 0.05 a$ & $1.43 \pm 0.06 a$ * & $2.89 \pm 0.16 \mathrm{a}$ & $3.24 \pm 0.09 a \mathrm{~ns}$ \\
\hline Sever & $0.80 \pm 0.07 \mathrm{~b}$ & $0.80 \pm 0.05 b \mathrm{~ns}$ & $2.49 \pm 0.17 a$ & $2.34 \pm 0.10 \mathrm{~b} n \mathrm{~s}$ \\
\hline Bread wheat mean & $0.97 \pm 0.09$ & $1.12 \pm 0.15$ * & $2.69 \pm 0.14$ & $2.79 \pm 0.21 \mathrm{~ns}$ \\
\hline Acalou & $1.34 \pm 0.06 a$ & $1.15 \pm 0.13 \mathrm{ans}$ & $3.86 \pm 0.18 \mathrm{a}$ & $3.75 \pm 0.06 \mathrm{a} n \mathrm{~s}$ \\
\hline TE 9306 & $1.79 \pm 0.05 b$ & $1.07 \pm 0.16 \mathrm{a}$ * & $4.31 \pm 0.07 a$ & $3.33 \pm 0.35 \mathrm{a} n \mathrm{~s}$ \\
\hline Durum wheat mean & $1.57 \pm 0.11$ & $1.11 \pm 0.09 * *$ & $3.39 \pm 0.23$ & $3.16 \pm 0.18$ * \\
\hline
\end{tabular}

Under heat stress, the protein content increased significantly in all genotypes (Table 3). These results agree with the conclusion reached by Correll et al. (1994) that during grain filling high temperatures $\left(>30^{\circ} \mathrm{C}\right)$ were related to a rise in grain protein levels; our results also agree with those of Wardlaw et al. (1989) and Guedira et al. (2002) even when the observed decrease of the grain weight is considered (Table 1). Moreover, the inverse relation between protein content which increased and the sedimentation index which decreased (Table 3) agree with the results obtained by Novaro et al. (1997) and Rharrabti et al. (2003) under Mediterranean conditions. During grain filling, the modifications in the grain protein content (Table 3), associated with high temperatures $\left(>30^{\circ} \mathrm{C}\right)$, have been related to reductions in the sedimentation index SDS (Graybosh et al., 1995) and seemed to promote a decrease in gluten strength. Data obtained in several studies carried out in the field and confirmed under controlled environments (Blumenthal et al., 1993; Stone and Nicolas, 1994; Wrigley et al., 1994; Panozzo and Eagles, 2000), indicate that a few days of maximum daily temperatures surpassing $32^{\circ} \mathrm{C}$ produce grains with weaker dough. This effect on the dough properties, involving modifications in the protein composition associated with high temperatures during grain growth has also been pointed out by several authors (Blumenthal et al., 1993; Wrigley et al., 1994). The lack of interaction genotype $x$ treatment for protein content in the bread wheat, and also in SDS for the bread and durum wheat (Table 3), might indicate an absence of genetic variability in the response of these traits to high temperatures. In bread wheat, the grain hardness increased significantly with heat stress (Table 3) which, according to Guedira et al. (2002), might be an important factor for the wheat technological value. An increase in grain hardness might modify the milling quality, since greater energy will be required for grain rupture procedures and the production of smaller particles (Finney et al., 1987). Additionally, this effect might also impair conservation and increase damage to starch grains during milling (Pomeranz and Williams, 1990).

Table 3. Bread and durum wheat grain technological quality. SDS = sodium dodecyl sulfate sedimentation test. For each Triticum species, different letters in the same column refer to significant differences between genotypes. Data represents the mean of three replicates $\pm \mathrm{SE}$; ns $=$ non-significant; ${ }^{\star \star}=P<0.01 ;{ }^{* \star \star}=$ $P<0.001$.

\begin{tabular}{lllllll} 
& \multicolumn{3}{c}{ Protein $(\%)$} & & \multicolumn{2}{c}{ Hardness (\%) } \\
\cline { 2 - 7 } & Control & Heat stress & Control & Heat stress & Control & Heat stress \\
\hline Golia & $13.78 \pm 0.24 \mathrm{a}$ & $16.95 \pm 0.41 \mathrm{a} * *$ & $62.67 \pm 0.33 \mathrm{a}$ & $60.00 \pm 2.08 \mathrm{a} \mathrm{ns}$ & $103.30 \pm 1.57 \mathrm{a}$ & $117.60 \pm 0.62 \mathrm{a} * *$ \\
Sever & $13.14 \pm 0.13 \mathrm{a}$ & $16.81 \pm 0.15 \mathrm{a} * * *$ & $80.00 \pm 2.52 \mathrm{~b}$ & $78.00 \pm 2.52 \mathrm{~b} \mathrm{~ns}$ & $26.90 \pm 1.50 \mathrm{~b}$ & $35.73 \pm 1.07 \mathrm{~b} * *$ \\
Bread wheat mean & $13.46 \pm 0.19$ & $16.88 \pm 0.19 * * *$ & $71.33 \pm 4.04$ & $69.00 \pm 4.28 \mathrm{~ns}$ & $65.12 \pm 17.12$ & $76.67 \pm 18.31 * * *$ \\
& & & & & & \\
Acalou & $13.82 \pm 0.12 \mathrm{a}$ & $17.43 \pm 0.06 \mathrm{a} * * *$ & $31.67 \pm 0.67 \mathrm{a}$ & $30.33 \pm 0.33 \mathrm{a} \mathrm{ns}$ & \\
TE 9306 & $14.69 \pm 0.05 \mathrm{~b}$ & $15.85 \pm 0.05 \mathrm{a} * * *$ & $29.33 \pm 0.88 \mathrm{a}$ & $27.67 \pm 0.33 \mathrm{~b} \mathrm{~ns}$ & \\
Durum wheat mean & $14.26 \pm 0.20$ & $16.64 \pm 0.36 * * *$ & $30.50 \pm 0.72$ & $29.00 \pm 0.63 *$ & & \\
\hline
\end{tabular}


The amino acid composition of proteins showed that the stability of Lys was strongly affected (18-30\%) under heat stress (Table 4). On the other hand, the levels of Thr, which is the second limiting amino acid (after Lys), increased significantly (5-40\%) with high temperatures (Table 4). Concerning nonessential amino acids of bread and durum wheat grains, only the contents of Arg and His vary significantly relative to controls (Table 5). The level of His decreased significantly (except in Acalou), between $10 \%$ and $26 \%$, in the durum and bread wheat genotypes. Under heat stress conditions, the contents of Arg also showed a similar trend, decreasing between $4-17 \%$.

Table 4. Essential amino acids of bread and durum wheat kernel at maturity under control and heat stress treatments. Data represents the mean of three replicates $\pm \mathrm{SE}$. Letters $\mathrm{a}, \mathrm{b}$ and $\mathrm{r}$, s indicate significant differences among treatments and genotypes, respectively. $\mathrm{C}=$ control; $\mathrm{HS}=$ heat stress; $\mathrm{BW}=$ bread wheat; DW $=$ durum wheat.

\begin{tabular}{|c|c|c|c|c|c|c|c|}
\hline \multicolumn{8}{|c|}{ Essential amino acids [mg $\left.(100 \mathrm{~g})^{-1}\right]$} \\
\hline & & & Sever & BW mean & Acalou & TE 9306 & DW mean \\
\hline \multirow[t]{2}{*}{ lle } & C & $377 \pm 20^{\text {ar }}$ & $387 \pm 20^{\text {ar }}$ & $382 \pm 11^{a}$ & $668 \pm 18^{\mathrm{ar}}$ & $649 \pm 32^{\text {ar }}$ & $659 \pm 17^{a}$ \\
\hline & HS & $369 \pm 14^{\text {ar }}$ & $416 \pm 19^{\text {ar }}$ & $393 \pm 15^{\mathrm{a}}$ & $639 \pm 21^{\text {ar }}$ & $639 \pm 15^{\text {ar }}$ & $639 \pm 15^{\mathrm{a}}$ \\
\hline \multirow[t]{2}{*}{ Leu } & C & $766 \pm 19^{\text {ar }}$ & $781 \pm 25^{\mathrm{ar}}$ & $773 \pm 15^{\mathrm{a}}$ & $984 \pm 27^{\text {ar }}$ & $969 \pm 30^{\text {ar }}$ & $976 \pm 18^{a}$ \\
\hline & HS & $752 \pm 14^{\text {ar }}$ & $765 \pm 25^{\mathrm{ar}}$ & $759 \pm 13^{\mathrm{a}}$ & $1021 \pm 40^{a r}$ & $937 \pm 35^{\text {ar }}$ & $979 \pm 30^{\mathrm{a}}$ \\
\hline \multirow[t]{2}{*}{ Lys } & C & $370 \pm 26^{\text {ar }}$ & $387 \pm 7^{\text {ar }}$ & $379 \pm 13^{\mathrm{a}}$ & $395 \pm 19^{\text {ar }}$ & $380 \pm 35^{\text {ar }}$ & $388 \pm 18^{a}$ \\
\hline & HS & $295 \pm 10^{\text {ar }}$ & $305 \pm 20^{\text {br }}$ & $300 \pm 10^{b}$ & $314 \pm 21^{\text {br }}$ & $261 \pm 37^{\text {ar }}$ & $287 \pm 22^{b}$ \\
\hline \multirow[t]{2}{*}{ Phe } & C & $478 \pm 10^{\text {ar }}$ & $540 \pm 11^{\text {as }}$ & $509 \pm 16^{a}$ & $766 \pm 27^{\text {ar }}$ & $672 \pm 20^{\text {ar }}$ & $719 \pm 26^{a}$ \\
\hline & HS & $468 \pm 26^{\text {ar }}$ & $513 \pm 27^{\mathrm{ar}}$ & $491 \pm 20^{a}$ & $756 \pm 23^{\text {ar }}$ & $653 \pm 34^{\text {ar }}$ & $705 \pm 29^{\mathrm{a}}$ \\
\hline \multirow[t]{2}{*}{ Thr } & $C$ & $433 \pm 22^{\mathrm{ar}}$ & $435 \pm 21^{\text {ar }}$ & $434 \pm 13^{a}$ & $449 \pm 13^{\mathrm{ar}}$ & $382 \pm 32^{\mathrm{ar}}$ & $415 \pm 21^{a}$ \\
\hline & HS & $589 \pm 8^{b r}$ & $522 \pm 29^{a r}$ & $555 \pm 20^{b}$ & $460 \pm 38^{a r}$ & $485 \pm 13^{\text {br }}$ & $473 \pm 19^{a}$ \\
\hline \multirow[t]{2}{*}{ Val+Met } & $C$ & $568 \pm 28^{\mathrm{ar}}$ & $544 \pm 24^{\mathrm{ar}}$ & $556 \pm 17^{\mathrm{a}}$ & $1935 \pm 55^{\text {ar }}$ & $1934 \pm 34^{\mathrm{ar}}$ & $1935 \pm 29^{a}$ \\
\hline & HS & $566 \pm 40^{\mathrm{ar}}$ & $589 \pm 8^{\mathrm{ar}}$ & $578 \pm 19^{a}$ & $1924 \pm 46^{\mathrm{ar}}$ & $1913 \pm 33^{\mathrm{ar}}$ & $1918 \pm 25^{a}$ \\
\hline
\end{tabular}

Table 5. Non-essential amino acids of bread and durum wheat kernel at maturity under control and heat stress treatments. Data represents the mean of three replicates \pm SE. Letters $\mathrm{a}, \mathrm{b}$ and $\mathrm{r}$, s indicate significant differences among treatments and genotypes, respectively.

$\mathrm{C}=$ control; $\mathrm{HS}=$ heat stress; $\mathrm{BW}=$ bread wheat; $\mathrm{DW}=$ durum wheat.

\begin{tabular}{|c|c|c|c|c|c|c|c|}
\hline \multicolumn{8}{|c|}{ Non-essential amino acids [mg $(100 \mathrm{~g})^{-1}$ ] } \\
\hline & & Golia & Sever & BW mean & Acalou & TE 9306 & DW mean \\
\hline \multirow[t]{2}{*}{ Ala } & C & $344 \pm 19^{\text {ar }}$ & $367 \pm 12^{\text {ar }}$ & $356 \pm 11^{a}$ & $732 \pm 55^{\text {ar }}$ & $626 \pm 69^{\text {ar }}$ & $679 \pm 46^{\mathrm{a}}$ \\
\hline & HS & $352 \pm 26^{\text {ar }}$ & $376 \pm 8^{\text {ar }}$ & $364 \pm 13^{\mathrm{a}}$ & $712 \pm 19^{a r}$ & $718 \pm 17^{\text {ar }}$ & $715 \pm 12^{\mathrm{a}}$ \\
\hline \multirow[t]{2}{*}{$\operatorname{Arg}$} & C & $729 \pm 37^{\text {ar }}$ & $721 \pm 15^{\text {ar }}$ & $725 \pm 18^{a}$ & $884 \pm 9^{\text {ar }}$ & $882 \pm 15^{\mathrm{ar}}$ & $883 \pm 8^{a}$ \\
\hline & HS & $623 \pm 36^{\text {ar }}$ & $622 \pm 17^{\text {br }}$ & $623 \pm 18^{b}$ & $714 \pm 22^{\text {br }}$ & $823 \pm 9^{\text {bs }}$ & $769 \pm 27^{b}$ \\
\hline \multirow[t]{2}{*}{ Asp } & C & $708 \pm 38^{\text {ar }}$ & $806 \pm 13^{\mathrm{ar}}$ & $793 \pm 19^{a}$ & $835 \pm 29^{a r}$ & $901 \pm 8^{\mathrm{ar}}$ & $868 \pm 20^{a}$ \\
\hline & HS & $735 \pm 24^{\text {ar }}$ & $786 \pm 7^{\text {ar }}$ & $761 \pm 16^{a}$ & $825 \pm 22^{\text {ar }}$ & $925 \pm 29^{\text {ar }}$ & $875 \pm 28^{a}$ \\
\hline \multirow[t]{2}{*}{ Gly } & $\mathrm{C}$ & $493 \pm 12^{\text {ar }}$ & $467 \pm 27^{\text {ar }}$ & $480 \pm 12^{\mathrm{a}}$ & $726 \pm 13^{\mathrm{ar}}$ & $745 \pm 28^{a r}$ & $736 \pm 14^{a}$ \\
\hline & HS & $507 \pm 18^{\mathrm{ar}}$ & $492 \pm 29^{\text {ar }}$ & $499 \pm 16^{a}$ & $740 \pm 15^{\mathrm{ar}}$ & $734 \pm 29^{\text {ar }}$ & $737 \pm 15^{\mathrm{a}}$ \\
\hline \multirow[t]{2}{*}{ His } & C & $329 \pm 10^{\mathrm{ar}}$ & $369 \pm 14^{\mathrm{ar}}$ & $349 \pm 12^{\mathrm{a}}$ & $399 \pm 12^{\mathrm{ar}}$ & $466 \pm 19^{\text {as }}$ & $433 \pm 18^{a}$ \\
\hline & HS & $275 \pm 8^{\mathrm{br}}$ & $295 \pm 13^{b r}$ & $285 \pm 13^{b}$ & $350 \pm 19^{a r}$ & $337 \pm 25^{b r}$ & $344 \pm 14^{b}$ \\
\hline \multirow[t]{2}{*}{ Pro } & C & $940 \pm 35^{\mathrm{ar}}$ & $964 \pm 46^{\mathrm{ar}}$ & $952 \pm 26^{a}$ & $1066 \pm 67^{\mathrm{ar}}$ & $1201 \pm 77^{\text {ar }}$ & $1133 \pm 55^{a}$ \\
\hline & HS & $935 \pm 24^{\text {ar }}$ & $963 \pm 32^{2 \mathrm{r}}$ & $949 \pm 19^{a}$ & $1118 \pm 19^{a r}$ & $1148 \pm 37^{\text {ar }}$ & $1133 \pm 20^{a}$ \\
\hline \multirow[t]{2}{*}{ Ser } & $C$ & $697 \pm 15^{\mathrm{ar}}$ & $733 \pm 28^{\mathrm{ar}}$ & $715 \pm 16^{a}$ & $764 \pm 33^{\mathrm{ar}}$ & $909 \pm 27^{\text {as }}$ & $837 \pm 38^{a}$ \\
\hline & HS & $687 \pm 12^{\mathrm{ar}}$ & $719 \pm 20^{\text {ar }}$ & $703 \pm 13^{a}$ & $789 \pm 24^{\text {ar }}$ & $902 \pm 28^{\text {as }}$ & $846 \pm 30^{\mathrm{a}}$ \\
\hline \multirow[t]{2}{*}{ Tyr } & $C$ & $292 \pm 15^{\mathrm{ar}}$ & $290 \pm 26^{\text {ar }}$ & $291 \pm 14^{\mathrm{a}}$ & $364 \pm 21^{\text {ar }}$ & $315 \pm 16^{\mathrm{ar}}$ & $339 \pm 16^{a}$ \\
\hline & HS & $291 \pm 8^{\text {ar }}$ & $329 \pm 18^{\text {ar }}$ & $310 \pm 12^{\mathrm{a}}$ & $400 \pm 13^{\mathrm{ar}}$ & $330 \pm 8^{\text {as }}$ & $365 \pm 17^{a}$ \\
\hline
\end{tabular}


The contents of $\mathrm{K}, \mathrm{Na}, \mathrm{Cu}$, and $\mathrm{Mn}$ in the grain were not affected by high temperatures, but the levels of $\mathrm{Ca}, \mathrm{Zn}$ and $\mathrm{Fe}$ in the grains of Sever increased significantly by about 3, 0.5 and 1 fold, respectively (Figures 4 and 5 ).
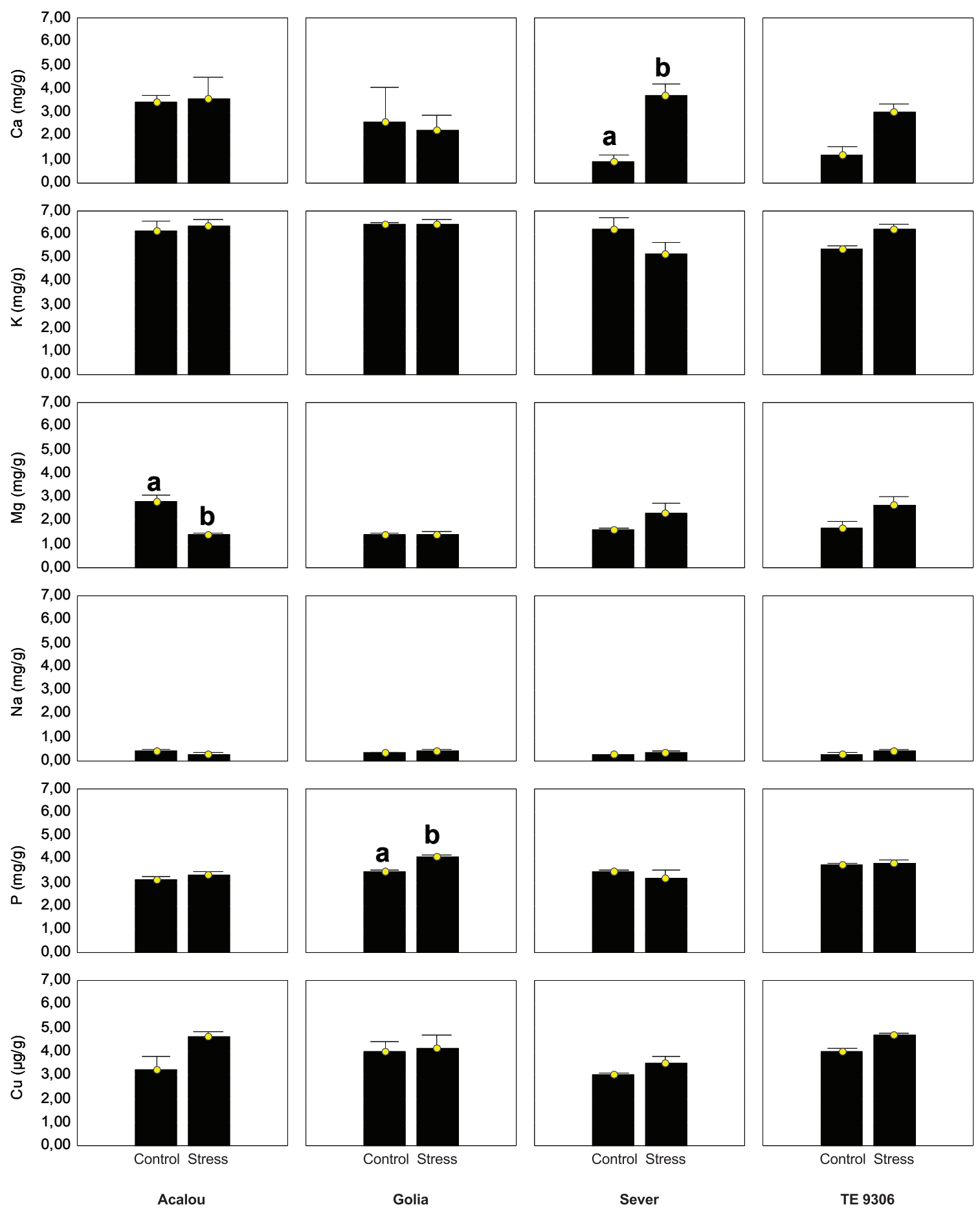

Figure 4. Nutrient concentrations in the bread and durum wheat kernels, under control and heat stress treatments. Data represents the mean of five replicates. Vertical bars represent SE. For each nutrient, means for each genotype marked with letters $a$ and $b$ are significantly different from each other. 
In Golia, only the concentrations of $\mathrm{P}$ increased (by 19\%) (Figure 4). Acalou followed an opposite trend, in comparison with the others genotypes, with high temperatures significantly decreasing the levels of $\mathrm{Mg}$ in the grain. Additionally, this genotype also showed a significant increase of Zn under heat stress conditions (ca. 100\%). In general, under control and heat stress conditions, the nutrient contents of the grains were not significantly different between both genotypes of each species (Figures 4 and 5). Yet, although under control conditions the level of Fe in the grain of Sever was significantly lower than in Golia, this difference could not be found under high temperature, suggesting a marked increase of this metal content in heat-stressed Sever (Figures 4 and 5). The nutrient contents of the grain, under heat stress, were similar to those found by Calderini and Ortiz-Monasterio (2003) in two varieties of bread wheat. The only exceptions were $\mathrm{Ca}$ and $\mathrm{Zn}$ which were higher in our work, probably reflecting specific genomic characteristics.
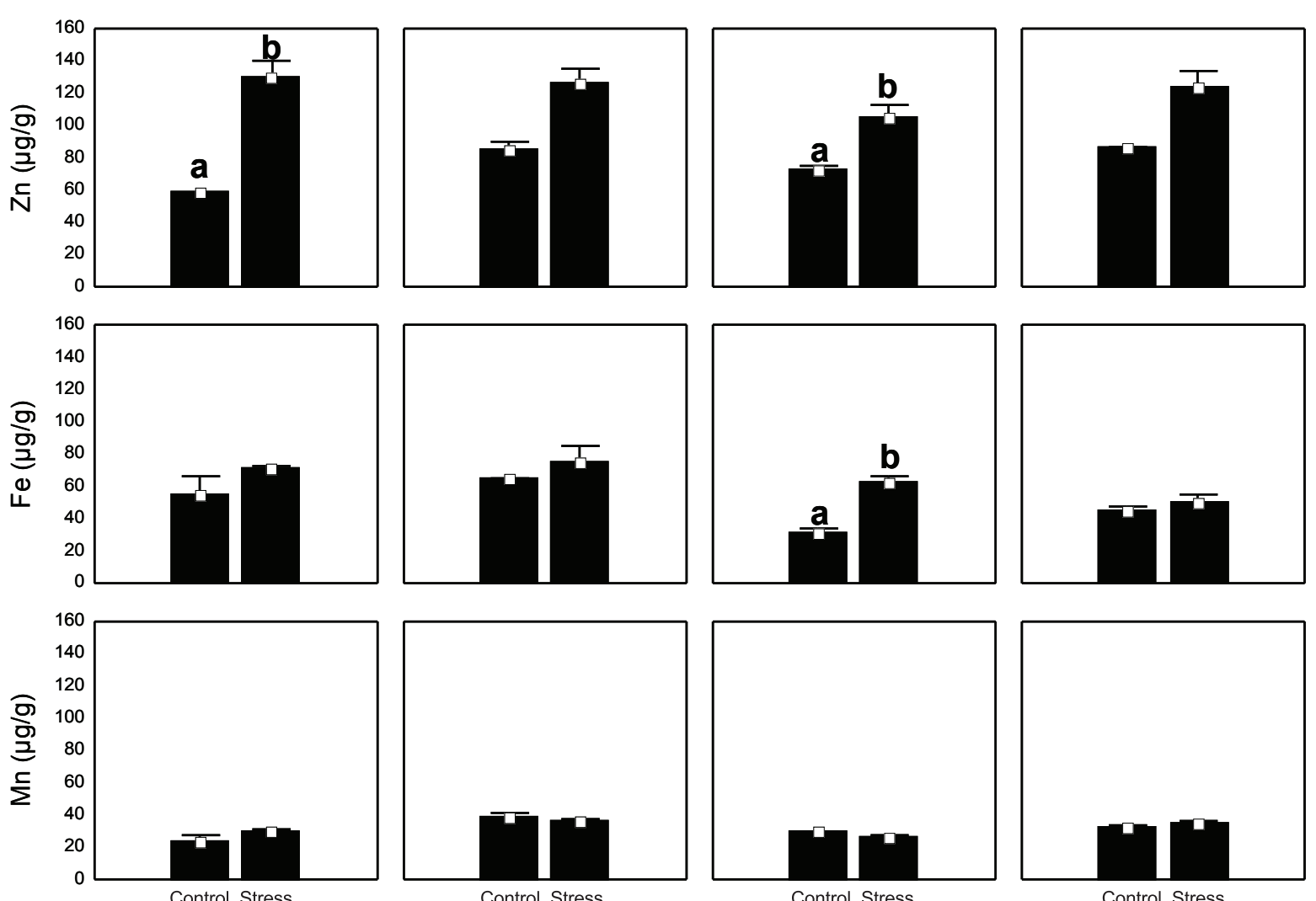

Acalou

Golia

Sever

TE 9306

Figure 5. Micronutrient concentrations in the bread and durum wheat kernels, under control and heat stress treatments. Statistics as in Figure 4.

\section{CONCLUSION}

At an ultrastructural level heat stress triggered changes in the aleurone layer and in the endosperm cells during grain filling. High temperatures, after anthesis, had negative effects on wheat quality, as indicated by the diminished levels of the essential amino acids in the grain following heat stress. A negative trend for the SDS test was associated with an increase in grain protein content, indicating that heat stress could indirectly reduce gluten strength during grain filling. 


\section{REFERENCES}

Araus JL, Amaro T, Casadesús J, Asbati A, Nachit MM (1998) Relationships between ash content, carbon isotope discrimination and yield in durum wheat. Aust. J. Plant Physiol. 25:835-842.

Bechtel DB, Zayas I, Kaleikau L, Pomeranz Y (1986) Quantitative image analysis and microscopy of wheat endosperm starch formation. Cereal Foods World. 31:602.

Blumenthal CS, Barlow EWR, Wrigley CW (1993) Growth environment and wheat quality: the effect of heat stress on dough properties and gluten proteins. J. Cereal Sci. 18:3-21.

Bradbury D, MacMasters MM, Cull LM (1956) Structure of the mature wheat kernel. III. Microscopic structure of the endosperm of hard red winter wheat. Cereal Chem. 33:361-373.

Branlard G, Dardevet M (1985) Diversity of grain protein and bread wheat quality. II. Correlation between high molecular weight subunits of glutenin and flour quality characteristics. J. Cereal Sci. 3:345-354.

Calderini DF, Ortiz-Monasterio I (2003) Are synthetic hexaploids a means of increasing grain element concentration in wheat? Euphytica. 134:169-178.

Chowdhury SI, Wardlaw IF (1978) The effect of temperature on kernel development in cereals. Aust. J. Agric. Res. 29:205-223.

Correl R, Butler J, Spouncer L, Wrigley C (1994) The relationship between grain-protein content of wheat and barley and temperatures during grain filling. Aust. J. Plant Physiol. 21:869-873.

Dick JW, Quick JS (1983) A modified screening test for rapid estimation of gluten strength in early-generation durum wheat breeding lines. Cereal Chem. 60:315-318.

Dupont FM, Altenbach SB (2003) Molecular and biochemical impacts of environmental factors on wheat grain development and protein synthesis. J. Cereal Sci. 38:133-146.

Finkelstein RR, Gibson SI (2001) ABA and sugar interactions regulating development: cross-talk or voices in a crowd. Curr. Opin. Plant Biol. 5:2632.

Finney KF, Yamarzaki WT, Youngs VL, Rubenthaler GL (1987) Quality of hard, soft and durum wheats. In: Heyne EG (ed), Wheat and Wheat Improvement, pp.677-748. ASA/CSSA/SSSA, Madison.

Gibson SI (2005) Control of plant development and gene expression by sugar signaling. Curr. Opin. Plant Biol. 8:93-102.

Guedira M, McCluskey PJ, MacRitchie F, Paulsen GM (2002) Composition and quality of wheat grown under different shoot and root temperatures during maturation. Cereal Chem. 79:397-403.

Hall JL, Hawes C (1991) Electron Microscopy of Plant Cells. Academic Press, New York.

Hayakawa K, Oizumi J (1989) Isocratic separation of phenylthiohydantoinamino acids by reversed phase HPLC. J. Chrom. 487:161-166.

Jenner CF (1991) Effects of exposure of wheat ears to high temperature on dry matter accumulation and carbohydrate metabolism in the grain of two cultivars. I. Immediate responses. Aust. J. Plant Physiol. 18:165-177.

Leon P, Sheen J (2003) Sugar and hormone connections. Trends Plant Sci. 8:110-116.

Lindsay H (1973) A colorimetric estimation of reducing sugars in potatoes with 3,5-dinitrosalicylic acid. Potato Res. 16:176.

Maçãs B, Gomes C, Dias AS (1999) Efeito das temperaturas elevadas durante 0 enchimento do grão em trigo mole e rijo no Sul de Portugal. Melhoramento. 36:27-45.

Maçãs B, Gomes MC, Dias AS, Coutinho J (2000) The tolerance of durum wheat to high temperatures during grain filling. In: Royo C, Nachit MM, Di Fonzo N, Araus JL (eds), Options Méditerranéennes. Durum wheat improvement in the Mediterranean region: new challenges, pp.257-261. CIHEAM, Zaragoza.
McDonald GK, Sutton BG, Ellison FW (1983) The effects of time of sowing on the grain yield of irrigated wheat in Namoi Valley, New South Wales. Aust. J. Agric. Res. 34:229-240.

Nicolas ME, Gleadow RM, Dalling MJ (1984) Effects of drought and high temperature on grain growth in wheat. Aust. J. Plant Physiol. 11:553-566.

Novaro P, D'Egidio MG, Bacci L, Mariani BM (1997) Genotype and environment: their effect on some durum wheat quality characteristic. J.Gen. Breed. 51:247-252.

Panozzo JF, Eagles HA (2000) Cultivar and environmental effects on quality characters in wheat. II. Protein. Aust. J. Agric. Res. 51:629-636.

Pomeranz Y (1988) Wheat Chemistry and Technology. Vol.2. American Association of Cereal Chemistry, St. Paul.

Pomeranz Y, Williams PC (1990) Wheat hardness: Its genetic, structural, and biochemical background, measurements and significance. In: Pomeranz Y (ed), Advances in Cereal Science and Technology, Vol. X, pp.471-544. American Association of Cereal Chemistry, St. Paul.

Pyler EJ (1988) Baking Science and Technology. Merriam, KS, USA Sosland Publishing).

Rharrabti Y, Villegas D, García del Moral LF, Aparicio N, Elhani S, Royo C (2001) Environmental and genetic determination of protein content and grain yield in durum wheat under Mediterranean conditions. Plant Breed. 120:381-388.

Rharrabti Y, Villegas D, Royo C, Martos-Núñez V, García del Moral LF (2003) Durum wheat quality in Mediterranean environments II. Influence of climatic variables and relationships between quality parameters. Field Crops Res. 80:133-140.

Shi YC, Seib PA, Bernardin JE (1994) Effects of temperature during grainfilling on starches from six wheat cultivars. Cereal Chem. 71:369-383.

Sofield I, Evans LT, Cook MG, Wardlaw IF (1977) Factors influencing the rate and duration of grain filling in wheat. Aust. J. Plant Physiol. 4:785-797.

Spiertz JHJ (1974) Grain growth and distribution of dry matter in the wheat plant as influenced by temperature, tight energy and ear size. Neth. J. Agric. Sci. 22:207-220.

Stone PJ, Nicolas ME (1994) Wheat cultivars vary widely in their responses of grain yield and quality to short periods of post-anthesis heat stress. Aust. J. Plant Physiol. 21:887-900.

Sumner JB (1925) A more specific reagent for the determination of sugar in urine. J. Biol. Chem. 65:393-395.

Thornley JHM (1971) Energy, respiration, and growth in plants. Ann. Bot. 35:721-728.

Vandecasteele C, Block CB (1993) Modern methods for trace element determination. John Wiley and Sons, Chichester.

Wang J, Eagles HA, Trethowan R, Ginkel M (2005) Using computer simulation of the selection process and known gene information to assist in parental selection in wheat quality breeding. Aust. J. Agric. Res. 56:465-473.

Wardlaw I F, Wrigley C W (1994) Heat tolerance in temperate cereals: an overview. Aust. J. Plant Physiol. 21:695-703.

Wardlaw IF, Dawson IA, Munibi P, Fewster R (1989) The tolerance of wheat to high temperatures during reproductive growth. I. Survey procedures and general response patterns. Aust. J. Agric. Res. 40:1-13.

Watanabe FS, Olsen SR (1965) Test of an ascorbic acid method for determining phosphorus in water and $\mathrm{NaHCO}_{3}$ extracts from the soil. Soil Sci. Soc. Am. Proc. 29:677-678.

Watts S, Halliwell L (1996) Appendix 3 - Detailed field and chemical methods for soil. In: Watts $S$, Halliwell $L$ (eds), Essential Environmental Science, Methods and Techniques, pp.475-505. Routledge, London.

Wiśniewski K, Zagdańska B (2001) Genotype-dependent proteolytic response of spring wheat to water deficiency. J. Exp. Bot. 52:1455-1463.

Wrigley CW, Blumenthal C, Gras PW, Barlow EWR (1994) Temperature variation during grain filling and changes in wheat-grain quality. Aust. J. Plant Physiol. 21:875-885. 